\title{
RBV Teori : Kinerja Religius Berbasis Kepribadian Islam dan Perilaku Inovatif Dalam Konseptual
}

\author{
Ali Jufri \\ Pebi Kurniawan \\ Mohammad Djadjuli \\ Imam Hadiwibowo \\ Universitas Muhammadiyah Cirebon (UMC) \\ jufri.ali2014@gmail.com
}

\begin{abstract}
This study tries to look at developments and emerging issues about resource-based displays. From the point of view of Penrose in 1959 about the need for companies to have competing resources, until Barney's compilation gave rise to a resource-based (RBV) view and valuable, rare, non-replicable, and irreplaceable (VRIN), and organizational (OIN) views in a place that can absorb and use them. Study reviews are used by using literature review studies by reviewing articles that are relevant to the theme. The RBV discussion starts with the 4-dimensional grouping of the RBV model, which is the focus of the renewal. The purpose of this study is to explore behavioral concepts in terms of Islamic personality that encourage innovative motivation so that individual targets can be increased not only because of the visible support for religious or belief in God.
\end{abstract}

Keywords: Innovative Behavior; Islamic Personality; RBV Theory; and Religious Performance

\section{Pendahuluan}

Resource-Based View (RBV) merupakan teori yang dikemukakan oleh Penrose, yang menyatakan bagaimana keunikan perusahaan dan aset khusus, serta konseptual merupakan sumber daya yang membangun keunggulan bersaing. (Giustiziero, et. al, 2019 (Giustiziero et al., 2020); Barney, 1991 (Barney, 1991); Mahoney \& Pandian, 1992 (Mahoney \& Pandian, 1992); Peteraf, 1993; 1984)(Helfat \& Peteraf, 2003). RBV memiliki kontribusi di bidang ilmu pengetahuan dengan menghasilkan 4 fokus argumen, yaitu : 1. Membuat keunggulan bersaing; 2. Keberlanjutan keunggulan bersaing; 3. Mekanisme yang membatasi; 4. Keunggulan dan Sewa Ekonomi. (Kor \& Mahoney, 2000; Rugman and Verbeke's, 2002; (Lockett \& Thompson, 2004).

RBV merupakan salah satu teori ekonomi yang berpandangan pada paradigma fungsionalis yang berakar kuat pada tradisi sosiologi kemapanan, ketertiban sosial, stabilitas sosial, kesepakatan, keterpaduan social, kesetiakawanan, pemuasan kebutuhan dan empirik. Paradigma ini cenderung objetivis, yaitu pendekatan kajian masalah berdasarkan objeknya. Namun dalam perjalanannya kaum positivism mengalami pergeseran sejak abad ke-20 dimana pemikiran Weber, Simmel dan GH Mead mulai meninggalkan rumusan teoritis kaum objektivis dan mulai bersentuhan dengan paradigma interpretif yang lebih subjektif. Sehingga RBV pun kemudian berkembang menjadi Resource-Based Theory dan The Growth Firms.

Pandangan berbasis sumber daya (RBV) memunculkan proposisi sentral bahwa jika perusahaan ingin mencapai keadaan Sustained Competitive Anvantages (SCA), perusahaan wajib memiliki sumber daya dan kemampuan yang unik dan berharga yang tidak dimiliki oleh 
kompetitor (VRIN), serta memiliki wadah organisasi (O) yang mampu menyerap kepentingan karyawan (Barney, 2001; Barney, 1991). Proposisi memiliki sejumlah analisis, yaitu core competence (Hamel \& Prahalad, 1994), kemampuan yang dinamis (Helfat \& Peteraf, 2003; Teece, Pisano, \& Shuen, 1997), dan pandangan menurut ilmu pengetahuan (Grant, 1996b).

RBV berpendapat bahwa sumber daya merupakan sumber keunggulan kompetitif dan bertanggung jawab atas perbedaan kinerja antar perusahaan (Burvill et al., 2018; Hoopes et al., 2003). Barney (2001) memberikan pengertian sumber daya merupakan modal fisik dan non fisik yang dipakai oleh perusahaan untuk membuat dan menjalankan strategi, sementara Wernerfelt (1984) dalam Miller, (2019) memberikan definisi sumber daya sebagai segala sesuatu yang dapat memberikan kekuatan atau kelemahan pada perusahaan. Asumsi utama RBV adalah perusahaan yang mampu bersaing ketika memiliki sumber daya yang unik dan berbeda sehingga menjadi Sustained Competitive Anvantages (Burvill et al., 2018; Barney \& Arikan, 2008) dan fokus utama adalah pada apa yang dapat dilakukan perusahaan dengan sumber daya (Burvill et al., 2018; Davidsson dan Wiklund, 2006; Nason \& Wiklund, 2018).

Barney dan Arikan (2001) dalam Barney \& Arikan, (2008) berpendapat bahwa untuk menjadi sumber keunggulan kompetitif, sumber daya harus bernilai, sehingga perusahaan lain sulit untuk meniru dan tidak ada sumber daya lain yang mampu menggantikannya. Kemudian, telah diperdebatkan bahwa sumber daya tidak perlu harus langka tetapi lebih dari yang biasa dan masih mampu memberikan perusahaan keunggulan kompetitif (Alfarisi, 2015; Burvill et al., 2018). Barney dan Arikan (2001) dalam Barney \& Arikan, (2008) menjelaskan jenis sumber daya yang dimiliki perusahaan, yaitu sumber daya berwujud, seperti keuangan dan modal fisik dan sumber daya tidak berwujud, seperti modal manusia dan hubungan. Sumber daya tidak berwujud sangat penting bagi banyak perusahaan berbasis pengetahuan dan karena kebangkitan ekonomi berbasis pengetahuan adalah inti mereka mencapai dan mempertahankan pertumbuhan (Riley dan Rob inson, 2011; Dal Borgo, et al., 2012; Burvill et al., 2018). Meskipun sumber daya tidak berwujud ini sangat penting, mereka mungkin lebih sulit untuk diteliti karena kurang didefinisikan (Chrisman et al., 1998; Levitas dan Chi, 2002; Burvill et al., 2018).

Literatur RBV juga menyinggung pentingnya kombinasi sumber daya yang berbeda melalui kumpulan sumber daya yang heterogen di seluruh perusahaan (Wernerfelt, 1984; Miller, 2019; Barney dan Arikan, 2001; Barney \& Arikan, 2008); Peteraf dan Barney, 2003; Helfat \& Peteraf, 2003; Burvill et al., 2018), tetapi yang kurang jelas adalah sumber daya spesifik mana yang perlu digabungkan dan dengan cara apa, untuk mempengaruhi pertumbuhan perusahaan.

Salder et al., (2020) mencoba merumuskan berbagai dimensi sumber daya yang bersaing berdasarkan pendapat-pendapat ahli, dengan membagi sumber daya menjadi 4 dimensi, yaitu Strategic, Asset, Characteristics dan Environment. 
Ali Jufri, Pebi Kurniawan, Mohammad Djadjuli, Imam Hadiwibowo

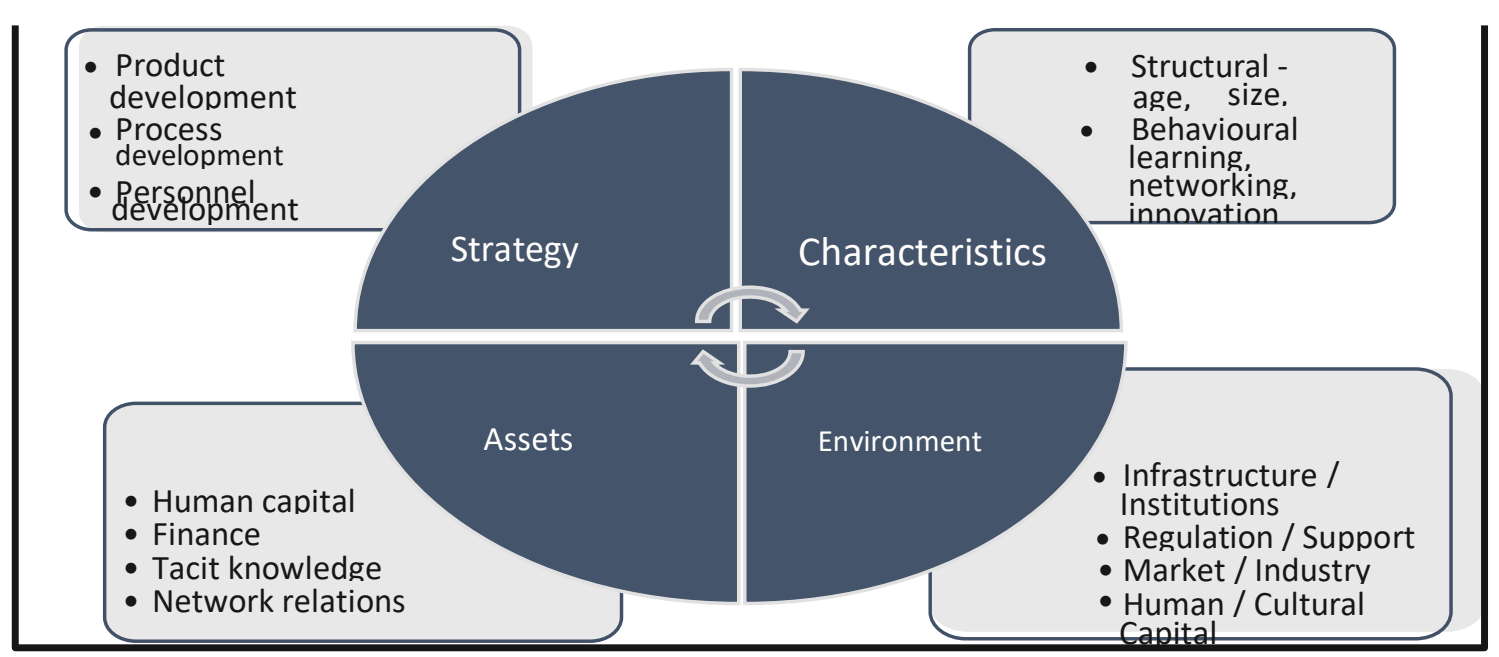

Gambar 1. The Four Dimensions Conceptual Model Sumber: Salder, et.al., (2020)

RBV erat kaitannya dengan dimensi karakteristik individu, salah satunya pola perilaku dan inovasi. Karakteristik biasanya selalu terbangun dari sebuah pola perilaku termasuk masalah keyakinan atau spiritualitas. Spiritualitas di tempat kerja merupakan pengalaman keterikatan dan interaksi diantara pekerja yang terkait dalam kegiatan kerja, di latarbelakangi oleh kemurnian, asas timbal balik, dan niat tulus, yang mampu menumbuhkan arti yang melekat ketika masuk dalam pekerjaan di sebuah organisasi, dan memberikan nilai motivasi serta keunikan yang dimiliki organisasi. (Marques et al., 2007; Marques, 2008). Internal support membuat perilaku spiritual sebagai pendorong, dijelaskan sebagai "perasaan senang dan bahagia", dalam penjelasan lain spiritual adalah suplemen dalam "kehidupan batin" dan "pribadi yang memiliki niat baik" dalam melakukan hubungan dengan lingkungan kerja. Perilaku spiritual merupakan perasaan yang terhubung dengan orang lain sebagai bagian dari lingkungan dan merupakan pengalaman dari keterikatan di antara mereka yang terkait dengan kegiatan kerja. (Giacalone \& Jurkiewicz, 2003); Ashmos Plowman \& Duchon (2005); Marques et al., 2007; Marques, 2008).

Dengan dorongan internal yang memiliki nilai spiritual diharapkan mampu memunculkan kinerja, sehingga kinerja religius tidak sama dengan kinerja biasa. Hal ini yang menginspirasi munculnya pembahasan tentang kinerja yang lebih spesifik, yaitu kinerja Religius. Kemudian, penguasaan ilmu pengetahuan dan teknologi oleh individu manusia akan memunculkan individu yang unggul dan bermanfaat untuk kepentingan umat manusia. Dalam Al Quran pada Surat As Zumar ayat 9 : "Katakanlah: samakah orang-orang yang berilmu dengan orang-orang yang tidak berilmu pengetahuan?" Hanya orang-orang mengertilah yang dapat memikirkannya. Perlu dipahami bahwa di negara Eropa dan Amerika sudah semakin banyak yang menyadari betapa pentingnya ketaatan beragama dalam meningkatkan kinerja. Fritjof Chapra dalam The Way of Life dan The Tao of Physic menjelaskan bahwa manusia semakin terpuruk akibat banyak manusia masih terjebak dalam paradigma yang serba sistematis, sehingga manusia masuk pada pola keangkuhan dan kebodohan. Inti masalahannya terletak pada kegamangan manusia mengakui adanya kuasa Tuhan, dalam setiap keberhasilan atau kegagalan yang terjadi pada setiap individu. Kelayakan kinerja religius akan terwujud pada hasil produksi yang Islami dan bersetifikasi halal, berkualitas, 
pelayanan Islami, efisien dan efektif, serta mampu merealisasikan kepuasan karyawan menuju keridhoan Allah SWT.

Salah satu yang membentuk kinerja religius adalah ketika individu membangun karaktek dirinya sesuai dengan syariah Islam atau yang sering disebut sebagai Akhlak atau kepribadian Islam. Imam Al-Ghazali mengemukakan pendapatnya tentang kepribadian dengan membedakan kepribadian manusia baik yang kasat mata (psikosufis) maupun tidak kasat mata (spiritual-metafisik). Dengan pandangan tersebut psikologi berbasiskan budaya ketimuran dan sendi-sendi nilai spiritualitas agama akan muncul sebagai identitas psikologi baru. Hal ini selaras dengan preposisi Uichol Kim, sebagaimana dikutip oleh Achmad Mubarok, bahwa manusia tidak cukup dipahami dengan teori psikologi Barat, karena psikologi Barat hanya tepat untuk mengkaji manusia Barat sesuai dengan kultur sekulernya yang melatarbelakangi lahirnya ilmu tersebut. Untuk memahami manusia, kita harus melihat wilayah geografi dan kultur budaya di mana manusia itu hidup. Dengan demikian Indonesia yang masuk dalam wilayah dan kultul budaya Ketimuran serta mayoritas penduduknya beragama Islam, maka integrasi kepribadian yang Islami diharapkan memunculkan perilaku inovatif seseorang dalam bekerja.

Perusahaan/Organisasi berusaha membangun suasana tempat kerja yang memadai bagi pekerjanya, hal tersebut bertujuan untuk memberikan kenyamanan dalam bekerja dan memudahkan pekerja untuk menemukan inovasi baru. Penciptaan organisasi dengan suasana kerja yang inovatif akan memudahkan respon cepat organisasi ketika muncul tantangan dari lingkungan dibandingkan dengan organisasi yang kurang inovatif cenderung tidak siap terhadap perubahan lingkungan yang semakin dinamis. Perilaku inovatif merupakan perilaku anggota organisasi untuk menemukan, mengelola, dan mengimplementasikan ide-ide baru, termasuk di dalamnya adalah produk, teknologi, prosedur, dan proses kerja. Tujuannya adalah untuk meningkatkan keefektifitasan kinerja anggota organisasi dan memberikan keuntungan bagi organisasi. Inovasi pada hakikatnya adalah sebuah ide yang datang dari individu, muncul dan implementasi ide yang inovatif (Etikariena \& Muluk, 2014). Saat ide inovatif menemui titik temu masalah yang ada dalam organisasi, maka proses perilaku inovatif dimulai (De Jong \& De Hartog, 2010). Janssen (2000) menjelaskan bahwa dalam berinovasi, ada tiga tahapan proses, yaitu idea generation, tahap dimana individu menggunakan kreativitasnya untuk menemukan sesuatu yang baru dan memiliki nilai manfaat bagi kemajuan organisasi atau perusahaan. Tahapan yang kedua adalah idea promotion, tahap menemukan dan mengumpulkan partner, sponsor, atau pendukung terhadap ide yang telah dihasilkan. Tahapan yang terakhir adalah idea realization, tahap pengimplementasian atau realisasi ide di dalam lingkungan kerja.

\section{Tinjauan Literatur}

\section{RBV Theory}

Dalam perkembangan teori RBV sendiri memiliki logika tautologi dimana dibangun berdasarkan logika proposional dimana Ludwig Wittgenstein menjelaskan bahwa dalam logika proposisional (memunculkan hubungan antar variabel sesuai dengan dasar teori) ada metode yang efektif untuk menguji apakah formula yang diberikan selalu dipenuhi (atau, setara, apakah efeknya tidak memuaskan/kontradiksi). Hal ini sesuai dengan pemahaman Hansonian dan Kuhnian yang memandang tidak ada kebenaran yang benar-benar objektif, bahwa kebenaran pengamatan akan bergantung pada teori, paradigm atau kerangka kerja dan asumsi-asumsi yang dimilikinya.

Perkembangan teori RBV dimulai dari studi Lippman \& Rumelt (1982) dalam Barney et al., (2011) yang menyatakan bahwa RBV berdasarkan situasi ketidakpastian yang 
menyebabkan perbedaan efisiensi di antara beberapa Perusahaan. Akuisi sumber daya keunggulan mencegah dari calon imitator untuk mengetahui secara pasti tentang apa yang ditiru atau bagaimana menirunya. Ditambah dengan nonrecoverable costs, ketidakpastian tersebut mampu mengurangi aktivitas imitatif, sehingga kondisi heterogenitas mampu dipertahankan. Kemudian ada Isolating mechanism, yaitu pembelajaran produser, biaya perpindahan pembeli, reputasi, biaya pencarian pembeli, saluran distribusi dan skala ekonomi terhadap aset khusus ketika diperlukan. Wernerfelt (1984) dalam Barney et al., (2011) memunculkan pemikiran bahwa RBV merupakan dasar keunggulan kompetitif yang intinya terletak pada sekumpulan kelompok aset berwujud atau tidak berwujud dari perusahaan. Yang paling monumental adalah studi Barney et al., (2011) yang menghadirkan dan mengembangkan prinsip inti RBV dengan menyajikan definisi sumber daya yang lebih terperinci dan mengartikulasikan dengan rangkaian karakteristik lengkap yang menjadi sumber daya sumber potensial keunggulan kompetitif, yaitu sumber daya berharga, unik, langka, tidak dapat ditiru, dan tidak dapat diganti.

Kemudian pada tahun 1990an berkembang tentang pandangan sumber daya berdasarkan kemampuan dan pengetahuan seperti yang dikemukakan oleh Kogut \& Zander (1992); Amit \& Schoemaker (1993); Grant (1996); Conner \& Prahalad (1996) dan Teece, Pisano, \& Shuen (1997). Di tahun 2007 Teece dalam Barney et al., (2011) mengemukakan gagasannya tentang sifat dan dasar mikro dari kemampuan yang diperlukan untuk mempertahankan kinerja perusahaan yang unggul dalam ekonomi terbuka dengan inovasi cepat dan tersebar secara global sumber penemuan, inovasi, dan kemampuan manufaktur. Selanjutnya muncul kritik terhadap RBV yang dikemukakan oleh Kraaijenbrink, Spender, \& Groen (2010); (Kraaijenbrink et al., 2010) dalam Barney et al., (2011) yang menyatakan tentang delapan kategori kritik terhadap RBV : (a) RBV tidak memiliki implikasi manajerial, (b) RBV menyiratkan kemunduran tak terbatas, (c) Penerapan RBV terlalu terbatas, (d) Sustained Competitive Advantage tidak dapat dicapai, (e) RBV adalah bukan teori perusahaan, (f) Sumber daya dan kemampuan yang berharga, langka, tak dapat ditiru, dan tidak dapat diganti (VRIN), serta memiliki organisasi (O) tidak diperlukan atau tidak cukup untuk SCA, (g) nilai sumber daya terlalu tidak pasti untuk menyediakan teori yang bermanfaat, dan (h) Definisi sumber daya tidak bisa diterapkan.

Perkembangan RBV selama beberapa dekade di atas, telah memberi kontribusi di bidang ekonomi dan manajemen strategis, baik yang berusaha untuk memperbaiki konsep RBV atau menggunakannya sebagai kerangka kerja untuk menjawab pertanyaan yang konseptual dan empiris. Kontribusi utama dari pandangan berbasis sumber daya perusahaan merupakan teori competitive advantage. Logika dasarnya adalah dimulai dengan asumsi bahwa hasil yang diinginkan dari upaya manajerial dalam perusahaan adalah keuntungan kompetitif yang berkelanjutan. Mencapai keunggulan kompetitif yang berkelanjutan, memungkinkan perusahaan untuk memperoleh 'economic rent' atau di atas rata-rata return.

\section{Kepribadian Islam}

Teori Sifat Kepribadian yang paling sering digunakan dalam dunia kerja adalah Teori Sifat Kepribadian "Model Lima Besar" atau "Big Five Personality Traits Model" yang dikemukakan oleh Seorang Psikolog terkenal yaitu Lewis Goldberg. Big Five Personality Traits Model memiliki 5 dimensi kunci, yaitu (1). Openness (Terbuka terhadap Hal-hal baru), (2). Conscientiousness (Sifat Berhati-hati), (3). Extraversion (tingkat kenyamanan dalam berinteraksi), (4). Agreeableness (Mudah Bersepakat) dan (5). Neuroticism (kemampuan menahan tekanan).

Pada konteks lokal dan ketimuran kepribadian menunjukkan temuan yang beragam bila dibandingkan dengan konstruk Big Five yang sudah mapan. Penelitian tentang 
kepribadian Melayu, menemukan bahwa item-item di dalam aspek Openness and Extraversion gagal membentuk struktur faktor yang jelas (Mastor, et.al, 2000; Kor \& Mahoney, 2000; Othman et al., 2014) Sebuah studi menggunakan NEO-PI-R di Indonesia (negara dengan populasi Islam terbesar) oleh Halim, Derksen dan van der Staak (2004) menunjukkan bahwa ada keandalan internal yang rendah untuk beberapa aspek dari konstruk Big Five dan Keterbukaan untuk membuat kecocokan dengan nilai-nilai Islam yang memunculkan jasa kepribadian yang melibatkan kebajikan dan perbuatan baik. Muslim dianggap sebagai hamba Tuhan dan Muslim harus melakukan perbuatan baik dalam kehidupan bisnis dan pribadi (Abbas \& Gibbs, 1998; Othman et al., 2014). Di dalam Surat Al Baqarah Allah SWT., berfirman, "Tetapi orang-orang yang beriman dan beramal saleh, Kami akan menerimanya di taman-taman di mana sungai mengalir (surga), tinggal di sana selamanya. Di sana mereka akan memiliki Azwajun Mutahharatun (pasangan atau istri yang telah dimurnikan), dan Kami akan mengakui mereka memiliki nuansa yang luas dan semakin dalam"(Al-Baqarah, 22).

Pola perilaku Muslim sebagian besar didasarkan pada keputusan terpimpin yang telah diungkapkan oleh Al-Quran dengan istilah 'Al-Rushd' yang merujuk pada kedewasaan, kebijaksanaan dan kekuatan untuk menegakkan kepatuhan (Adnan \& Wan Chik, 2008; Othman et al., 2014). Di dalam Surat An Nahl, Allah SWT., berfirman, "Undanglah ke jalan Tuhanmu dengan kebijaksanaan dan instruksi yang baik, dan berdebatlah dengan mereka dengan cara yang terbaik. Sungguh, Tuhanmu paling mengetahui siapa yang menyimpang dari jalan-Nya, dan Dia paling mengetahui siapa [yang] dibimbing"(An-Nahl, 125). Berdasarkan premis ini, kemudian diusulkan konsep perilaku konsumen Islam yang menganjurkan pemasar, pembuat kebijakan dan konsumen untuk menampilkan nilai-nilai kebaikan, seperti ketekunan, penghematan, moderasi dan keseimbangan antara dunia ini dan akhirat. (Adnan, 2011; Othman et al., 2014). Extraversion dan Openness to Experience domain harus dilihat secara berbeda dalam pengaturan sosial Muslim, terutama ketika perempuan diharuskan mengenakan jilbab, pria dan wanita dilarang saling berbaur (kecuali untuk suami / istri atau anggota keluarga), dan ajaran tidak boleh menyimpang dari apa yang telah diajarkan 1400 tahun yang lalu melalui Quran dan Sunnah. Dalam Suratul Fussilat, Allah berfirman, "Dan kamu tidak menutupi dirimu sendiri, jangan sampai pendengaranmu bersaksi melawan kamu atau pandanganmu atau kulitmu, tetapi kamu berasumsi bahwa Allah tidak tahu banyak tentang apa yang kamu lakukan" (Al-Fussilat, 22). Ketika lima kepribadian besar dilihat berdasarkan perspektif individu muslim, orang diajari untuk bertanggung jawab dan menjauhkan diri dari melakukan dosa (teliti), sabar dan tawakkal yang berarti sepenuh hati (stabilitas emosi), musyawarah yang berarti konsultasi (kesesuaian), menahan diri dari berbicara tidak produktif (berlawanan dengan extraversion) dan menunjukkan kesederhanaan dan menjunjung tinggi nilai-nilai konservatif awalnya diajarkan oleh Quran dan nabi Muhammad (kebalikan dari keterbukaan terhadap pengalaman). Penjelasan di atas dapat dikatakan betapa pentingnya karakteristik tertentu yang harus dimiliki oleh umat Islam sehingga mereka akan mencapai kesuksesan dalam hidup mereka.

Dengan demikian muncul Model Kepribadian Islam, yaitu, 'Al-Rushd', yang meliputi ketekunan, penghematan, moderasi, dan keseimbangan; 'Jilbab', yang mencerminkan merawat nama baik seseorang, tidak melakukan dosa, sabar dan tawakkal yang berarti sepenuh hati (stabilitas emosional); musyawarah, yang berarti konsultasi (kesesuaian); menahan diri dari berbicara secara tidak produktif dan menunjukkan kesederhanaan; kerja tim, konsultatif, partisipatif, egaliter (kesetaraan); dan spiritualitas, yang meliputi ibadah (shalat), amanah (kejujuran), dan ilm (pengetahuan). (Othman et al., 2014). 


\section{Perilaku Inovatif}

Inovasi muncul dari kontribusi setiap individu. Secara pandangan psikologi organisasi, aktifitas-aktifitas individu merupakan innovative work behavioral (perilaku inovatif) (Janssen, 2000). Janssen (2000) mengartikan perilaku inovatif sebagai penemuan, pengenalan dan pengaplikasian ide-ide baru secara sengaja dalam suatu pekerjaan, kelompok, atau organisasi untuk memperoleh keunggulan dan manfaat dalam kinerja suatu pekerjaan, kelompok atau organisasi. Pengertian ini membatasi perilaku inovatif sebagai bentuk usaha yang sengaja dilakukan untuk mendatangkan hasil baru yang menguntungkan. Janssen (2000) kemudian menambahkan bahwa perilaku inovatif memiliki perilaku kompleks yang terdiri dari tiga tahap, yaitu (1) idea generation,(2) idea promotion, (3) idea realization.

De Jong \& Hartog (2007) dalam Pitelis, (2007) memunculkan dimensi perilaku inovatif menjadi empat, yaitu (1) Oppurtunity exploration, proses inovasi ditentukan oleh kesempatan; (2) Idea generation, membangkitkan sebuah konsep untuk peningkatan; (3) Championing, melibatkan perilaku untuk mencari dukungan dan membangun koalisi; (4) Application, individu mengevaluasi dan mengaplikasikan ide dalam tindakan nyata

\section{Kinerja Religius}

Terdapat 5 dimensi tingkat keagamaan seseorang, yaitu (1) keyakinan (ideologis), (2) peribadatan (ritual), (3) penghayatan (eksperiensial), (4) pengamalan (konsekuensial), (5) pengetahuan dan pemahaman Agama (Ancok, 1995; Muafi, 2003). Keyakinan terdiri dari nilai harapan dimana seseorang yang memiliki nilai religi untuk berpegang teguh pada pandangan teologis tertentu dan mengakui kebenaran terhadap doktrin agamanya. Aspek agama mencakup perilaku ritual keagamaan dan ketaatan seseorang untuk menunjukkan komitmen terhadap agama yang dianutnya. Di sisi penghayatan berisikan pengalamanpengalaman, persepsi yang dialami seseorang dalam beragama. Pengetahuan dan pemahaman Agama mengacu pada orang-orang religius yang minimal memiliki pengetahuan mengenai dasar-dasar keyakinan, kitab suci dan tradisi. Pada aspek pengamalan merupakan akibatakibat keyakinan keagamaan, praktek, pengamalan dan pengetahuan seseorang dari hari ke hari.

Sudut pandang Islam menilai ada beberapa indikator yang digunakan untuk mengukur kinerja religius (Zadjuli, 1999; Muafi, 2003), yaitu niat bekerja untuk mengharapkan ridho Allah, ketika bekerja mencoba menggunakan nilai syariah secara kaffah, keyakinannya adalah mencari "keuntungan" di dunia dan "keselamatan" di akherat, menjalankan prinsip efisiensi dan asas manfaat dengan tetap menjaga kelestarian hidup, menjaga keseimbangan untuk mencari harta dan tetap beribadah, tidak konsumtif sebagai rasa syukur kepada Allah SWT., membayarkan Zakat Infak Sodaqoh, dan memberi santunan terhadap fakir miskin dan anak yatim piatu. Konsekuensi yang didapatkan dari kesempurnaan manusia sebagai mahluk Allah SWT., maka manusia dituntut untuk bekerja secara sungguh-sungguh. (Muafi, 2003).

\section{Metode Penelitian}

Studi kali ini menggunakan pendekatan studi literature review dimana kami mencoba melakukan review teori RBV dengan menggunakan artikel-artikel yang relevan dengan topik yang diambil. Literature review mencakup pembahasan, resume dan pemahaman para ahli tentang beberapa sumber pustaka (tulisan dalam artikel, buku, slide ppt, informasi dari internet, dll) tentang tema yang dibahas. 


\section{Hasil dan Pembahasan}

\section{Hubungan Kepribadian Islam Dengan Kinerja Religius}

Allport (1994) yang dikutip oleh (Hung, 2020) menunjukkan bahwa kepribadian adalah pola respons yang stabil dan tahan lama terhadap stimulus luar dari lingkungan. Karenanya, kepribadian terlibat dalam pembentukan perilaku. Beberapa penelitian telah menggunakan ciri-ciri kepribadian sebagai prediktor untuk mempelajari perilaku di tempat kerja. Perilaku ini termasuk kepuasan karyawan dan komitmen afektif (Matzler \& Renzl, 2007; Aristovnik, Seljak, \& Tomazevic, 2016; (Hung, 2020), perilaku kewarganegaraan organisasi (Organ, 1994; (Hung, 2020), kinerja pekerjaan (Ashton, 1998; (Hung, 2020)), perilaku kerja kontraproduktif (Mount, et.al, 2006; (Hung, 2020), dll. Studi-studi ini menunjukkan kepada kita bahwa kepribadian adalah anteseden penting bagi berbagai perilaku di tempat kerja, terutama kinerja pekerjaan. (Hung, 2020)

Pandangan saat pengujian kepribadian, menyimpulkan bahwa hubungan kepribadian dengan kinerja pekerjaan itu kompleks tetapi konstruksi dan ukuran kepribadian yang digunakan saat ini memiliki potensi untuk memajukan penelitian dan praktik organisasi. (Hough dan Oswald, 2008; (Christiansen \& Tett, 2008) Secara fundamental kita memiliki peran situasi dalam memahami hubungan antara sifat-sifat kepribadian dan kinerja pekerjaan, khususnya yang berkaitan dengan teori aktivasi sifat (Tett \& Burnett, 2003; Tett \& Guterman, 2000; Christiansen \& Tett, 2008) (Christiansen \& Tett, 2008) sebagai panduan untuk penelitian lebih lanjut. Hough dan Oswald mengakui bahwa teori semacam itu berpotensi menyoroti di mana dan bagaimana variabel kepribadian paling mungkin memengaruhi perilaku dan kinerja. Di sini, kami memperluas komentar itu, meminta perhatian pada bagaimana tujuan umum ini mungkin paling baik dicapai. Kami mulai dengan beberapa pengamatan. Hough dan Oswald mengajukan pertanyaan apakah situasi itu penting dan bagaimana penelitian dapat memasukkan situasi atau konteks ke dalam pengukuran variabel kepribadian. (Christiansen \& Tett, 2008)

Studi oleh Galbraith \& Galbraith (2007) yang dikutip oleh Rulindo \& Mardhatillah, (2011) melakukan proses konfirmasi atas temuan studi sebelumnya, yang menemukan partisipasi individu dalam agama dan tingkat religiusitas keluarga mereka secara positif dikaitkan dengan wirausaha. (Woodrum, 1985; Honig, 1988; Kwon,1997; Champion, 2003; Martes \& Rodriguez, 2004; Galbraith, et. al., 2004). Honig (1988) menemukan bahwa kehadiran karyawan untuk beribadah di Gereja mampu meningkatkan kinerja bisnis karena modal sosial yang dihasilkan dari kegiatan ke Gereja mampu memperkuat hubungan dan menciptakan peluang di antara para pengusaha. (Rulindo and Mardhatillah, 2011)

Preposisi 1 : Hubungan Kepribadian Islam Dengan Kinerja Religius

\section{Hubungan Kepribadian Islam Dengan Perilaku Inovatif}

Islam memberikan pengajaran bahwa nilai nominal dalam perilaku hidup adalah mengamati dan mengamalkan kerja secara kelompok, konsultatif, partisipatif, pandangan kesetaraan pada karyawan di organisasi yang berbasis kaum Muslim (Tayeb, 1997; (Othman et al., 2014). Nilai-nilai ini terutama Kesadaran dan Agreeableness diposisikan dengan baik untuk menjadi bagian tak terpisahkan dari konstruksi ukuran kepribadian Islam yang diusulkan. Ini didukung oleh temuan bahwa karakteristik kepribadian mendasar dari orang beragama, terlepas dari budaya adalah kesesuaian dan hati nurani. (Saroglou, 2010; (Othman et al., 2014). Menjadi pribadi yang teliti adalah salah satu ciri kepribadian yang dapat dipahami dalam Islam. Ketaatan pada kepercayaan Islam membangun kesadaran penuh kepada Tuhan walaupun diri pribadi sedang mengalami suasana sibuk dalam mengejar realitas fisik, sehingga mengarah pada harmoni internal yang merupakan sumber kesehatan 
mental dan stabilitas emosional. Pernyataan ini didukung oleh penemuan Abdel-Khalek (2010) baru-baru ini bahwa religiositas dianggap sebagai faktor yang berkontribusi terhadap kualitas hidup di kalangan umat Islam. (Othman et al., 2014).

Baru-baru ini, (Othman et al., 2014) mengusulkan Ummatic Personality Inventory (UPI) yang membangunnya dibagi menjadi tiga komponen utama yaitu ibadah (sholat), amanah (kejujuran), dan ilm (pengetahuan). Selain itu Othman juga membagi kepribadian menjadi beberapa 5 faktor penting, yaitu (1) Al-Deen (agama Islam); (2) Al-Nasab (keturunan); (3) Al-Aqal (pikiran); (4) Al-Mal (kekayaan); (5) Al-Nafs (pribadi). Istilah maqasid juga diterjemahkan dari bahasa Arabnya sebagai teori tujuan dan maksud hukum Islam yang lebih tinggi. Berkaitan dengan Al-Deen adalah aqidah, atau keyakinan seseorang kepada Allah (Tuhan). Ini juga penting karena itu adalah perlindungan sistem kehidupan yang ditentukan oleh Islam, seperti dalam pendidikan, politik dan ekonomi. Ini sejalan dengan perintah Al-Quran, "Sesungguhnya satu-satunya agama di sisi Allah adalah Islam." Gagasan yang sama muncul dalam ayat lain, "Wahai orang-orang yang beriman, datanglah ke Islam secara keseluruhan." Fardhu Kifayah merupakan pengukuran kesediaan dan tindakan individu dalam melindungi dan memunculkan nilai-nilai Islam sebagai jalan hidup. Namun, ada beberapa batasan, model UPI yang didasarkan murni pada metode kuantitatif yang instrumennya sepenuhnya bergantung dan divalidasi dari Al-Quran dan As-Sunnah. (Othman et al., 2014) Meskipun sangat penting untuk memastikan bahwa teori dasar didasarkan pada Kitab Suci Islam dan Nabi Muhammad melihat, pandangan, wawasan dari praktisi muslim dan psikolog dapat memperkaya konstruk dengan nilai-nilai perilaku potensial yang hilang di UPI, seperti menampilkan semangat wirausaha Islam, mengendalikan emosi melalui pengampunan dan menetapkan batasan saat menerapkan kreativitas dan inovasi.

\section{Preposisi 2 : Hubungan Kepribadian Islam Dengan Perilaku Inovatif}

\section{Hubungan Kinerja Religius Dengan Perilaku Inovatif}

De Jong \& Hartog (2007) mengatakan bahwa perilaku inovatif kerja adalah perilaku yang mencakup pencarian peluang dan ide-ide baru, perilaku mengimplementasikan ide baru, penerapan pengetahuan baru dan pencapaian peningkatan kinerja individu atau bisnis. Dalam literatur bisnis dan manajemen, satu perluasan spiritualitas yaitu spiritualitas di tempat kerja telah muncul sebagai faktor penting dalam pengembangan organisasi. Neck dan Milliman (1994) yang dikutip oleh Janssen (2010), misalnya, mencatat bahwa spiritualitas dapat meningkatkan kinerja organisasi. Pendapat ini didukung oleh penelitian lain, seperti McCormick (1994), Brandt (1996), Leigh (1997), dan Mirvis (1997) yang melaporkan organisasi yang berupaya mempromosikan pengembangan spiritual kepada anggota mereka, mengalami peningkatan kreativitas, kepuasan karyawan, kinerja tim dan komitmen organisasi (Konz and Ryan, 1999). Khusus untuk kreativitas dan inovasi, Neck dan Miliman (1994) juga percaya bahwa spiritualitas dapat mengarah pada peningkatan inovasi jika organisasi bersedia memfasilitasi karyawan untuk mengembangkan visi organisasi yang lebih terarah dan lebih kuat. Ini terjadi karena banyak karyawan menjadi lebih kreatif ketika mereka merasa organisasi menawarkan mereka tujuan yang tulus. Sebagai akibatnya, organisasi semacam ini mampu menarik dan mempertahankan karyawan paling kreatif dalam industri.

Muncul satu cara bagi Perusahaan untuk lebih inovatif, yaitu memanfaatkan kemampuan karyawan untuk melakukan inovasi. Pekerjaan menjadi lebih berbasis pengetahuan dan tidak terlalu kaku, ketika karyawan dapat membantu meningkatkan kinerja bisnis melalui kemampuan mereka untuk menghasilkan ide dan menggunakannya sebagai konseptual membangun sebuah produk, layanan, dan proses kerja yang baru dan lebih baik. Banyak praktisi dan akademisi sekarang mendukung pandangan bahwa inovasi individu 


\section{Ali Jufri, Pebi Kurniawan, Mohammad Djadjuli, Imam Hadiwibowo}

membantu mencapai kesuksesan organisasi (Van de Ven, 1986; Amabile, 1988; Axtell et al., 2000; Smith, 2002; Unsworth dan Parker, 2003; De Jong and Hartog, 2007).

Untuk mewujudkan aliran inovasi yang berkelanjutan, karyawan harus mau dan mampu berinovasi. Inovasi individu merupakan pusat dari beberapa prinsip manajemen yang terkenal, termasuk manajemen kualitas total (McLoughlin and Harris, 1997; Ehigie and Akpan, 2004; De Jong and Hartog, 2007), skema peningkatan berkelanjutan (Boer dan Gieskes, 1998; De Jong \& Hartog, 2007), Kaizen (Imai, 1986; De Jong and Hartog, 2007), penjelajahan perusahaan (Elfring, 2003; De Jong and Hartog, 2007), dan pembelajaran organisasi (Senge, 1990; De Jong and Hartog, 2007). Inovasi individu telah dioperasionalkan dengan berbagai cara. Sebagai contoh, konstruk telah dipikirkan dalam hal karakteristik kepribadian (Hurt et al., 1977; De Jong and Hartog, 2007) atau keluaran (West, 1987; De Jong and Hartog, 2007). Yang lain telah mengambil perspektif perilaku (Janssen, 2000). Kami mengambil garis yang sama dengan yang terakhir dan mengatasi pengaruh pemimpin terhadap perilaku inovatif individu karyawan. Banyak penelitian perilaku pada inovasi individu berfokus pada kreativitas, misalnya, tentang bagaimana para pemimpin dapat merangsang generasi ide. Namun, kapan dan bagaimana ide-ide kreatif diimplementasikan, bagian penting dari proses inovasi, masih menjadi bahan penelitian.

Preposisi 3 : Hubungan Kinerja Religius Dengan Perilaku Inovatif

\section{Kesimpulan dan Saran}

Semua organisasi selalu berusaha untuk meningkatkan kinerja, tujuannya agar organisasi dapat bertahan dalam lingkungan dimana organisasi itu berada dan beroperasi. Mencari, membentuk dan mempertahankan keunggulan bersaing, merupakan tujuan dari organisasi. Keunggulan kompetitif organisasi dapat diukur dengan penilaian kinerja yang diharapkan mampu melebihi hasil kinerja pesaingnya. Organisasi wajib memiliki sumberdaya yang kuat dan inovatif yang menjadi salah satu syarat mutlak suatu organisasi untuk memperoleh keunggulan kompetitif. Sumber daya dalam organisasi dapat didefinisikan sebagai elemen yang penting dalam proses pencapaian goal Perusahaan baik aspek SDM (human resources), maupun SD non manusia (nonhuman resources). SDM adalah sumber daya yang terdapat dalam organisasi, yang meliputi semua orang yang melakukan aktivitas dengan kemampuan dan kekuatan fisik serta intelktual. Setiap Perusahaan berusaha untuk mendapatkan sumber daya yang unggul dan terbaik, karena dengan sumber daya yang handal diharapkan Perusahaan bisa bertahan dalam lingkungan kompetisi yang semakin dinamis. Perusahaan dengan sumber daya yang unggul juga diharapkan mampu untuk mendapatkan dan mempertahankan keunggulan kompetitifnya.

Pembedaan sumber keunikan dan kepemilikan sumber daya yang dimiliki oleh setiap organisasi sangat mutlak merupakan prinsip pembentukan strategi organisasi yang dikenal sebagai resource-based view (RBV). (Penrose, 1959 ; Barney, 1991) (Barney, 1991). Pada tahun 1991, Barney mencoba menghadirkan dan mengembangkan prinsip inti RBV, yaitu menyajikan definisi sumber daya yang terperinci dan mengartikulasikan serangkaian karakteristik lengkap yang menjadikan sumber daya sumber potensial keunggulan kompetitif (yaitu bernilai, unik, langka, tidak bisa ditiru, dan tidak ada pengganti). Perpektif pendekatan teori resource-based view menunjukkan pada sumber daya organisasi secara kapabilitas yang menjadi sumber keunggulan bersaing. Gambaran di atas memberikan pemahaman tentang sumber daya perusahaan harus memiliki keunggulan dan ketahanan dalam menghadapi kompetisi, sehingga keberkelanjutan perusahaan dapat dipertahankan, danorganisasi mampu melakukan pengolahan dan penyaluran sumber daya yang tepat. Pembahasan pada manajemen strategik, resource-based view berhubungan dengan sumber daya dan kapabilitas 
yang memungkinkan perusahaan untuk mendapatkan dan mempertahankan keuntungan bersaing yang berkelanjutan dan mencapai tujuan dari pendekatan resource-based view.

Konsep RBV sendiri mendapat kritik dari beberapa pakar yang menganggap kesulitan untuk mencari dan mendapatkan keunggulan sumber daya yang nyata. Dalam studi ini kemudian menawarkan sebuah konsep pendekatan secara Religius, terutama dari sisi pendekatan agama Islam sebahgai agama yang banyak dianut di Indonesia. Ketika terjadi musibah seperti terjangkitnya virus Corona, membuat banyak Negara-negara sekuler Barat semakin membolehkan aktivitas keagamaan muncul untuk diperdengarkan, seperti Adzan. Dalam kondisi seperti ini, maka spiritualitas pada kalangan masyarakat Amerika dan Eropa cenderung mengalami peningkatan. Sebenarnya sejak lama masyarakat Amerika secara umum mulai mempercayai bahwa Tuhan merupakan pusat kekuatan spiritual yang positif dan aktif (Kahmat, 2000 ; Mitroff, Ian I., Elizabeth A Denton, 1999 , Muafi, 2003). Waktu kali pertama, Max Weber melakukan kajian hubungan antara etos kerja dan agama, Weber memperoleh hasil penelitian salah satunya menyatakan bahwa agama ternyata memiliki kemampuan untuk membangun dan meningkatkan kekuatan kerja serta motivasi menuju pada kenyataan yang riil.

Apalagi dengan masyarakat yang semakin individualis dan materialistis membuat peran Agama menjadi sentral untuk membangun karakter individu pekerja yang kuat dan ungggul. Perilaku inovatif yang dibangun dengan konsep kepribadian Barat ternyata kurang relevan ketika diterapkan di Negara-Negara Islam, seperti Indonesia. Maka munculah sebuah konsep kepribadian Islam yang kuat dan unggul, yaitu Model Kepribadian Islam, yaitu (1) AlRushd mencakup tentang keuletan, penghematan, moderasi dan keseimbangan; (2) Jilbab dijelaskan sebagai proses penjagaan nama baik seseorang, tidak melakukan dosa, sabar dan tawakkal yang berarti sepenuh hati (stabilitas emosional); (3) Musyawarah, yaitu melakukan konsultasi (kesesuaian); (4) Menghindari pembicaraan yang tidak produktif dan memperlihatkan kesederhanaan; kerja tim, konsultatif, partisipatif, egaliter (kesetaraan); (5) Spiritualitas mencakup ritual ibadah (shalat), amanah (kejujuran), dan ilmu pengetahuan. (Othman et al., 2014).

Di masa yang akan datang diharapkan model kepribadian Islam mampu menjadi motor kemajuan organisasi yang ada di Indonesia. Dengan munculnya kepribadian yang unggul, kuat dan amanah dapat memunculkan manusia Indonesia yang Inovatif dan memiliki capaian kinerja yang bukan hanya berkiblat pada kinerja berbasis profit material tetapi juga bertumpu pada sebuah keyakinan bahwa kinerja merupakan bentuk ibadah kepada Allah SWT.

\section{Daftar Pustaka}

Abdul Kadir Othman, Muhammad Iskandar Hamzah and Nurhazirah Hashim (2014) Conceptualizing the Islamic Personality Model. Procedia-Social and Behavioral Sciences 130 (2014) $114-119$.

Arum Etikariena, Hamdi Muluk. (2014). Correlation between Organizational Memory and Innovative Work Behavior. Makara Human Behavior Studies In Asia, 18(2), 77-88. DOI:10.7454/mssh.v18i2.3463.

Blessing Kudzai Mabenge, Grace Portia Kuda Ngorora-Madzimure \& Charles Makanyeza, (2020). Dimensions Of Innovation And Their Effects On The Performance Of Small And Medium Enterprises : The Moderating Role Of Firm's Age And Size. Journal Of Small Business \& Entrepreneurship. https://doi.org/10.1080/08276331.2020.1725727. 
Carol M. Connell, (2008). Firm And Government As Actors In Penrose's Process Theory Of International Growth : Implications For The Resource-Based View And OwnershipLocation-Internationalisation Paradigm. Australian Economic History Review, Vol. 48, No. 2 July 2008. ISSN 0004-8992. doi: 10.1111/j.1467-8446.2008.00235.

Christos N. Pitelis, (2007). A Behavioral Resource-Based View of the Firm : The Synergy of Cyert and March (1963) and Penrose (1959). Organization Science 18(3) : 478-490. http://dx.doi.org/10.1287/orsc.1060.0244.

Constance E. H Elfat And M Argaret A . Peteraf. (2003). The D Ynamic Resource-Based View : Capability Lifecycles. Strategic Management Journal. Strat. Mgmt. J ., 24: 9971010 (2003). Published online in Wiley Inter Science (www.interscience.wiley.com). DOI: $10.1002 / \mathrm{smj} .332$.

Craig E. Armstrong and Katsuhiko Shimizu, (2007). A Review of Approaches to Empirical Research on The Resource Based View of the Firm. Journal of Management. DOI: $10.1177 / 0149206307307645$.

Douglas Miller. (2019). The Resource-Based View of The Firm. Business Policy and Strategy. DOI: 10.1093/acrefore/9780190224851.013.4.

Henry F.L. Chung, Zhujun Ding, Xufei Ma, (2019). Organisational Learning and Export Performance of Emerging Market Entrepreneurial Firms: The Roles Of RBV Mechanism and Decision-Making Approach. European Journal of Marketing. https://doi.org/10.1108/EJM-08-2017-0496.

Jay B. Barney And Asli M. Arikan, (2001). The Resource-Based View: Origins And Implications.

Jay B. Barney, (2001). Resource-Based Theories Of Competitive Advantage : A Ten Year Retrospective On The Resource-Based View. Journal of Management 27 (2001) 643650.

Jay B. Barney, (2011). The Future of Resource-Based Theory: Revitalization or Decline? Journal of Management, Vol. 37 No. 5, September 2011 1299-1315. DOI: 10.1177/0149206310391805.

Jeroen De Jong \& Deanne Den Hartog. (2007). How Leaders Influence Employees' Innovative Behaviour. European Journal of Innovation Management. January 2007 DOI: $10.1108 / 14601060710720546$.

Khalid Almarria and Paul Gardiner. (2014). Application of resource-based view to project management research: supporters and opponents. Procedia-Social and Behavioral Sciences 119 (2014) 437-445.

Magdalena S. Halim, J J. L. Derksen and C P. F. van der Staak, (2004). Development of the Revised-Neo Personality Inventory for Indonesia: A Preliminary Study. Proceedings from the 16th International Congress of the International Association for Cross-Cultural Psychology.

Muafi, (2003). Pengaruh Motivasi Spiritual Karyawan Terhadap Kinerja Religius: Studi Empiris Di Kawasan Industri Rungkut Surabaya (SIER). JSB No. 8 Vol. 1 Th. 2003. ISSN : 0853 - 7665.

Neild Christiansen And Robert P. Tett, (2008). Toward A Better Understanding Of The Role Of Situations In Linking Personality, Work Behavior, And Job Performance. Industrial and Organizational Psychology, 1 (2008), 312-316. 1754-9426/08.

Neild Christiansen, (2008). Toward a Better Understanding of The Role of Situations in Linking Personality, Work Behavior and Job Performance. Industrial and Organizational Psychology, 1 (2008), 312-316. 
Nooraini Othman, (2011). Exploring The Ummatic Personality Dimensions From The Psycho-Spiritual Paradigm. International Journal of Psychological Studies Vol. 3, No. 2; December 2011. doi:10.5539/ijps.v3n2p37.

Onne Janssen, (2010). Job demands, perceptions of effort-reward fairness and innovative work behavior. Journal of Occupational \& Organizational Psychology. First published: 16 December 2010. https://doi.org/10.1348/096317900167038

Salder, J., Gilman, M., Raby, S., \& Gkikas, A. (2020). Beyond Linearity and Resource-Based Perspectives of SME Growth. Journal of Small Business Strategy, 30 (1), 1-17.

Samantha Marie Burvill, Dylan Jones-Evans, Hefin Rowlands, (2018). Reconceptualising The Principles Of Penrose's (1959) Theory And The Resource Based View Of The Firm: The Generation Of A New Conceptual Framework. Journal of Small Business and Enterprise Development, https://doi.org/10.1108/JSBED-11-2017-0361

Walter C. Borman, Louis A. Penner, Tammy D. Allen and Stephan J. Motowidlo. (2001). Personality Predictors of Citizenship Performance. International Journal Of Selection And Assessment, Volume 9 Numbers 1/2 March/June 2001.

Wei-Tien Hung, (2018). Revisiting Relationships Between Personality And Job Performance: Working Hard And Working Smart. Total Quality Management, 2018. https://doi.org/10.1080/14783363.2018.1458608.

Alfarisi, M. A. (2015). ( Studi Perbandingan Ibrahim Elfiky dan Mario Teguh ). Studi. https://doi.org/10.1002/mrdd.20112

Barney. (1991). special theory forum the resource-based model of the firm: origins, implications, and prospects.

Barney, J. B. (2001). Resource-based theories of competitive advantage: A ten-year retrospective on the resource-based view. Journal of Management, 27(6), 643-650. https://doi.org/10.1177/014920630102700602

Barney, J. B., \& Arikan, A. M. (2008). The Resource-based View: Origins and Implications. The Blackwell Handbook of Strategic Management, 123-182. https://doi.org/10.1111/b.9780631218616.2006.00006.x

Barney, J. B., Ketchen, D. J., \& Wright, M. (2011). The future of resource-based theory: Revitalization or decline? Journal of Management, 37(5), 1299-1315. https://doi.org/10.1177/0149206310391805

Burvill, S. M., Jones-Evans, D., \& Rowlands, H. (2018). Reconceptualising the principles of Penrose's (1959) theory and the resource based view of the firm: The generation of a new conceptual framework. Journal of Small Business and Enterprise Development, 25(6), 930-959. https://doi.org/10.1108/JSBED-11-2017-0361

Christiansen, N. D., \& Tett, R. P. (2008). Toward a Better Understanding of the Role of Situations in Linking Personality, Work Behavior, and Job Performance. Industrial and Organizational Psychology, 1(3), 312-316. https://doi.org/10.1111/j.17549434.2008.00054.x

Giustiziero, G., Somaya, D., \& Wu, B. (2020). A Resource-Based Theory of Hyperspecialization and Hyperscaling. SSRN Electronic Journal, 1-43. https://doi.org/10.2139/ssrn.3531111

Helfat, C. E., \& Peteraf, M. A. (2003). The dynamic resource-based view: Capability lifecycles. Strategic Management Journal, 24(10 SPEC ISS.), 997-1010. https://doi.org/10.1002/smj.332

Hung, W. T. (2020). Revisiting relationships between personality and job performance: working hard and working smart. Total Quality Management and Business Excellence, 31(7-8), 907-927. https://doi.org/10.1080/14783363.2018.1458608 
Kor, Y. Y., \& Mahoney, J. T. (2000). Penrose's Resource-Based Approach: The Process and Product of Research Creativity. Journal of Management Studies, 37(1). https://doi.org/10.1111/1467-6486.00174

Kraaijenbrink, J., Spender, J. C., \& Groen, A. J. (2010). The Resource-based view: A review and assessment of its critiques. Journal of Management, 36(1), 349-372. https://doi.org/10.1177/0149206309350775

Lockett, A., \& Thompson, S. (2004). Edith Penrose's Contributions to the Resource-based View: An Alternative Perspective. Journal of Management Studies, 41(1), 193-203. https://doi.org/10.1111/j.1467-6486.2004.00428.x

Mahoney, J. T., \& Pandian, J. R. (1992). RBV.pdf. 13(April 1991), 363-380. https://doi.org/10.2307/2486455

Miller, D. (2019). The Resource-Based View of the Firm. Oxford Research Encyclopedia of Business and Management, 4(May), 1-21. https://doi.org/10.1093/acrefore/9780190224851.013.4

Nason, R. S., \& Wiklund, J. (2018). An Assessment of Resource-Based Theorizing on Firm Growth and Suggestions for the Future. Journal of Management, 44(1), 32-60. https://doi.org/10.1177/0149206315610635

Othman, A. K., Hamzah, M. I., \& Hashim, N. (2014). Conceptualizing the Islamic Personality Model. Procedia - Social and Behavioral Sciences, 130, 114-119. https://doi.org/10.1016/j.sbspro.2014.04.014

Pitelis, C. N. (2007). A behavioral resource-based view of the firm: The synergy of cyert and March (1963) and Penrose (1959). Organization Science, 18(3), 478-490. https://doi.org/10.1287/orsc.1060.0244

Salder, J., Gilman, M., Raby, S., \& Gkikas, A. (2020). Beyond linearity and resource-based perspectives of SME growth. Journal of Small Business Strategy, 30(1), 1-17. 